\title{
Interspecific gene flow and maintenance of species integrity in oaks
}

\author{
O. Gailing, Al. L. Curtu
}

Gailing O., Curtu Al. L., 2014. Interspecific gene flow and maintenance of species integrity in oaks. Ann. For. Res. 57(1): 5-18, 2014.

\begin{abstract}
Oak species show a wide variation in morphological and physiological characters, and boundaries between closely related species are often not clear-cut. Still, despite frequent interspecific gene flow, oaks maintain distinct morphological and physiological adaptations. In sympatric stands, spatial distribution of species with different ecological requirements is not random but constrained by soil and other micro-environmental factors. Here, we discuss factors that may influence the maintenance of the integrity of oak species in the face of interspecific gene flow. Pre-zygotic isolation (e.g. cross incompatibilities, asynchrony in flowering, pollen competition) and post-zygotic isolation (divergent selection) contribute to the maintenance of species integrity in sympatric oak stands. The antagonistic effects of interspecific gene flow and divergent selection are reflected in the low genetic differentiation between hybridizing oak species at most genomic regions interspersed by regions with signatures of divergent selection (outlier regions). In the near future, the availability of high-density genetic linkage maps anchored to scaffolds of a sequenced $Q$. robur genome will allow to characterize the underlying genes in these outlier regions and their putative role in reproductive isolation between species. Reciprocal transplant experiments of seedlings between parental environments can be used to characterize selection on outlier genes. High transferability of gene-based markers will enable comparative outlier screens in different oak species. Keywords Quercus, hybridization, outlier loci, ecological speciation.
\end{abstract}

Authors. Oliver Gailing - Michigan Technological University, 1400 Townsend Drive, 49931 Houghton, MI, United States, Alexandru Lucian Curtu (lucian. curtu@utbv.ro) - University of Transilvania Braşov, Dept. of Forest Sciences, Şirul Beethoven - 1, Brasov - 500 123, Romania

Manuscript received January 25, 2014; revised March 25, 2014; accepted April 02, 2014; online first April 07, 2014.

\section{Introduction}

Natural hybridization between species is a relatively common phenomenon in plants and has played an important role in the evolution of certain genera (Ellstrand et al. 1996). The occurrence of gene flow between closely related plant species has various impacts on spe- 
ciation and adaptation processes (Barton 2001, Strasburg et al. 2012, Abbott et al. 2013). Thus, interspecific gene flow may facilitate the transfer of genetic variants that promote adaptation (Arnold 2004) and the invasion of late-successional species into the range of a pioneer species (Petit et al. 2003). However, the homogenizing effect of gene flow on allele frequencies of different populations (species) can be mitigated through isolation by distance (IBD) and isolation by ecology or environment (IBE). In the latter pattern, which seems to be predominant (Sexton et al. 2014), dispersal limitations and selection against migrants due to local adaptation may decrease the rate of successful gene flow (Wright 1943).

Oaks are both economically and ecologically important keystone forest tree species by providing food and shelter for wildlife, and wood and paper products for human use (McShea et al. 2007, Aldrich \& Cavender-Bares 2011). They are mostly distributed throughout the Northern hemisphere (Nixon 1993, Aldrich \& Cavender-Bares 2011) but can also be found in the southern hemisphere - Quercus humboldtii in Colombia (Ávila et al. 2010). Genus Quercus comprises more than 500 species subdivided into several distinct monophyletic groups (Manos et al. 1999, Manos \& Stanford 2001). White oaks (section Quercus) are distributed across the Americas and Eurasia, red oaks (section Lobatae), live oaks (section Virentes), golden cup oaks (section Protobalanus) are restricted to the Americas, while cerris oaks (section Cerris) and cycle cup oaks (subgenus Cyclobalanopsis) occur in Eurasia and Asia, respectively (Aldrich \& Cavender-Bares 2011). Closely related oak species frequently hybridize where distribution ranges overlap (e.g. Ellstrand et al. 1996, Petit et al. 2003). The propensity of many oak species to hybridize has challenged the biological species concept (Mayr 1942), and oaks served as a model in the development of a species concept that is founded on ecological criteria (Van Valen 1976). The occurrence of hybridization in oaks was often inferred from morphological characters (Rushton 1993), which may show high phenotypic plasticity (Rieseberg 1995, Craft et al. 2002, Curtu 2006). More recently genetic assignment and paternity analyses at co-dominant genetic markers allowed the identification of putative hybrids as genetically intermediate individuals and of contemporary interspecific gene flow in sympatric stands (Streiff et al. 1999, Curtu et al. 2007a).

Oak species are characterized by considerable variation in morphological and physiological characters as the result of phenotypic plasticity, within-species genetic variation and interspecific hybridization (Aldrich \& Cavender-Bares 2011). Consequently, no single diagnostic morphological or genetic marker can unambiguously distinguish one species from other members of the same taxonomic section (Kremer et al. 2002, Mariette et al. 2002, Hipp \& Weber 2008). Even leaf morphological traits that are frequently used for species identification show a large variability within species and overlapping frequency distributions among species making the distinction of closely related species at single characters difficult. However, multivariate analyses using a set of morphometric, numeric and observed leaf characters in sympatric populations can often be used to differentiate between closely related species with some overlap in the phenotypic extremes (Jensen et al. 1993, Kremer et al. 2002, Curtu et al. 2007a, Gailing et al. 2012, Viscosi et al. 2012, Yucedag \& Gailing 2013). Putative hybrids have been described based on morphological characters (Jensen et al. 1993, Rushton 1993) and/or genetic assignment analyses using discriminating genetic markers (e.g. Neophytou et al. 2011, Lind \& Gailing 2013). In many cases genetic and morphological assignments yielded similar results with regard to the identification of species and hybrids. However, incongruencies between morphological and genetic assignment were also observed and can be due to high morphological variation and maternal effects. For 
example, maternal effects were described to account for the occurrence of first generation hybrids ( $F_{1}$ hybrids) that are phenotypically similar to the maternal parent (Cottam et al. 1982, Bacilieri et al. 1995, Kleinschmit et al. 1995, Kremer et al. 2002, Curtu et al. 2007a). Controlled crosses for example between the European white oak species $Q$. robur and $Q$. petraea showed that $F_{1}$ seedlings resembled the female parent (Steinhoff 1993).

The main goal of this review paper is to discuss the factors that influence the maintenance of species integrity in oaks in spite of the existence of gene flow between closely related species. We summarize experimental and molecular genetic studies on oak species from different areas of their natural distribution.

\section{Experimental interspecific crosses}

Hybridization networks developed for oak species, mainly based on the description of morphological intermediacy in the literature (Burns \& Honkala 1990, Aldrich \& CavenderBares 2011), showed a frequent occurrence of hybrids within sections, but absence of hybrids between distantly related species (e.g. between red oaks and white oaks). While hybrids between white and red oaks were not found in nature, very few putative hybrids from experimental crosses are reported in the literature (Cottam et al. 1982). Controlled crosses confirmed that many species within one section, even with disjunct natural distribution ranges, are interfertile, but also showed partial or complete incompatibility for some crosses (Figure 1). For example, using experimental crosses, a strong pre-zygotic isolation was observed between $Q$. petraea (female parent) and Q. robur (male parent)(Steinhoff 1998, Kleinschmit \& Kleinschmit 2000, Lepais et al. 2013) and between $Q$. ilex (female parent) and $Q$. suber (male parent) (Boavida et al. 2001). On the other hand, incompatibilities between $\mathrm{F}_{1}$ hybrids and one or both parental species appeared to be reduced potentially facilitating gene flow between sympatric species with partial incompatibilities. For example, a rare Q. petraea $\mathrm{X}$. robur $\mathrm{F}_{1}$ hybrid could be backcrossed efficiently with both parents possibly allowing nuclear gene flow from $Q$. robur to $Q$. petraea (Olrik $\&$ Kjaer 2007). Likewise, seeds collected from a hybrid between $Q$. lobata and $Q$. douglasii were fathered by both $Q$. lobata $(37 \%)$ and $Q$. douglasii (63\%), while only seven out of 394 Q. lobata acorns had mixed ancestry (Abraham et al. 2011). Also, environmental factors might affect the frequency of hybrid formation by reducing the success of conspecific pollen under stress conditions. For example, interspecific crosses between Q. gambelii and Q. grisea at two contrasting sites in New Mexico (mesic valley bottom, xeric mountain ridge) showed reduced fruit set in interspecific as compared to conspecific crosses. However, this difference was less pronounced at the xeric site suggesting that environmental stress might favor hybrid formation (Williams et al. 2001).

Also, experimental crosses showed that many species with disjunct natural distribution ranges produce viable $\mathrm{F}_{1}$ seedlings (Cottam et al. 1982, Figure 1). In the future, shifts of species distribution ranges as result of changing climate, and introduction of non-native species might increase the frequency of hybridization between formerly disjunct oak species.

\section{Genetic admixture in multispecies oak stands}

Hybrids can be distinguished from parental species using Bayesian clustering methods based on genetic marker information in software packages such as STRUCTURE (Pritchard et al. 2000) or NEWHYBRIDS (Anderson $\&$ Thompson 2002). The power of these analyses depends on the number of genetic markers that discriminate between species. Ideally, many markers should be screened before an appropriate set of informative markers is se- 


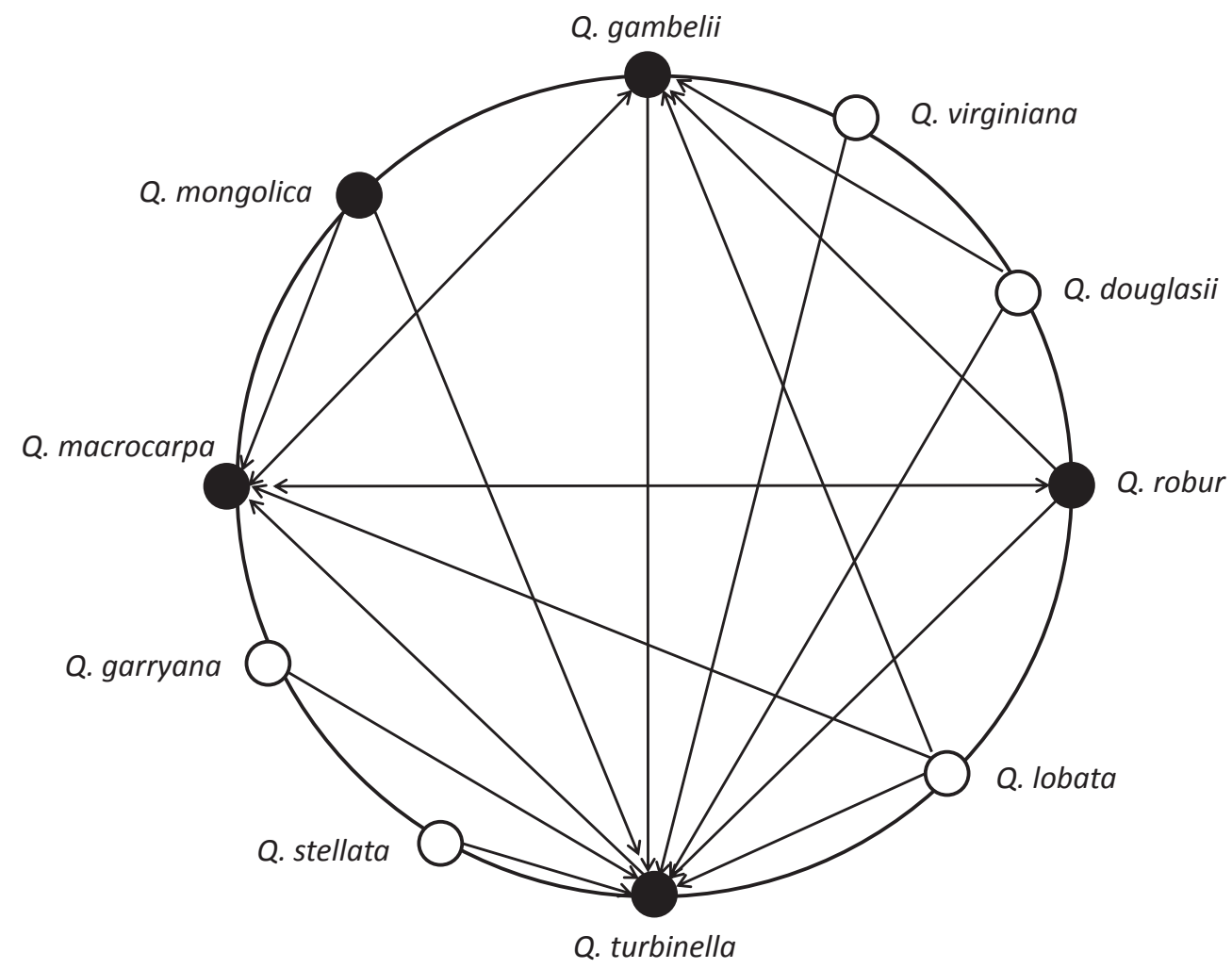

Figure 1 Results from artificial interspecific crosses according to Cottam et al. (1982). Filled circles represent species used as female and male parents. Species represented by open circles were used only as pollen donor. Distribution ranges of most species are disjunct. Natural hybrids have been described between Q. turbinella and Q. gambelii and between Q. turbinella and Q. douglasii (Rushton 1993)

lected. This pre-screening step is critical since the genetic differentiation between closely related oak species is generally very low at selectively neutral genetic markers as the result of past and ongoing interspecific gene flow and incomplete lineage sorting (Bodénès et al. 1997, Muir \& Schlötterer 2005, Lind \& Gailing 2013). The availability of gene-based markers (EST-SSRs, Expressed Sequence Tag-Simple Sequence Repeats) for white (Durand et al. 2010, Bodénès et al. 2012) and red oaks (Fagaceae Genomics web, http://www. fagaceae.org/markers) with high transferability among species (Bodénès et al. 2012, Sullivan et al. 2013) allows for the pre-selection of gene markers with putative roles in adaptive species differences (see below). Genetic assignment analyses often include markers with pronounced interspecific frequency differences (so called outlier loci) that might be involved in adaptive species differences or linked to these genomic regions (see below) (Curtu et al. 2007a, Lind \& Gailing 2013). Genetic markers commonly used in oaks were co-dominant isozymes, genomic and gene-based microsatellites (gSSRs, EST-SSRs) or dominant markers such as Amplified Fragment Length Polymorphisms (AFLPs) (Curtu et al. 2007a, Hipp \& Weber 2008, Curtu et al. 2011a). The number of putative hybrids varied among studies and was dependent for example on the species, the number of informative markers (unpublished results), the relative abundance of the species, environmental conditions affecting the availability of con-specific and hetero-specific pollen, and the geographical location or age of the hybrid zone (e.g. Jensen et al. 2009, Lepais et al. 2009, Lepais \& Gerber 2011, Lagache et 
al. 2013). Putative hybrids and introgressive forms were identified wherever closely related interfertile oak species come into contact, but their frequency at least in the adult tree generation was often comparatively low (Craft et al. 2002). Selection against hybrids was suggested as a post-zygotic isolation mechanism that could explain the absence of hybrid swarms as reflected in the relatively low number of putative hybrids in contact zones between interfertile oak species (Curtu et al. 2007a, 2009). In accordance with this hypothesis ancient contact zones between the two closely related Chinese oaks, Q. mongolica and Q. liaotungensis, showed lower hybrid frequencies than more recent hybrid zones, possibly as the result of selection against hybrids that had reinforced reproductive barriers in the ancient hybrids zones, but not yet in the more recent ones (Zeng et al. 2011). Likewise, based on genetic assignment and paternity analyses (see below), higher frequencies of putative interspecific hybrids were found in more recent hybrid zones at the northern distribution range of $Q$. robur and Q. petraea (Jensen et al. 2009) than in other studies in Europe (Streiff et al. 1999), one of them using the same genetic markers (Curtu et al. 2007a). If this observation holds true, it would have implications for the frequency of hybridization in the face of changing distribution ranges as the result of climate change and human-mediated transport of reproductive material.

Since hybridization might be more common in the secondary contact zones between species in the future, it is important to better understand the role of hybridization in adaptive evolution and its possible consequences such as transfer of adaptations between species (Arnold 2004, Arnold \& Martin 2011), increase of intraspecific adaptive variation, nuclear capture as a mechanism of invasion of one species into another species' range (Petit et al. 2003) or extirpation of rare species by asymmetric gene flow (Levin et al. 1996). It seems obvious that changing distribution ranges of oak species and environmental conditions will affect both pre- and post-zygotic isolation between oak species (Williams et al. 2001) and produce new contact zones between formerly allopatric species.

\section{Gene flow analyses in mixed oak stands}

In order to estimate levels of past and ongoing gene flow it is necessary to identify hybrids and introgressive forms in different life stages using genetic assignment and gene flow analyses. Genetically intermediate individuals may be the result of incomplete lineage sorting in recently diverged species and/or of past and contemporary interspecific gene flow. However, the spatial location of genetically intermediate individuals in the contact zones between species and accordance of genetic assignment with gene flow analyses suggested their origin from recent interspecific gene flow, rather than shared ancestral polymorphisms between species (Curtu et al. 2007a, 2009, de Heredia et al. 2009, Valbuena-Carabana et al. 2007).

Con- and hetero-specific pollen donors can be identified within sympatric oak stands by comparison of multi-locus genotypes of adult trees and seedlings (paternity analyses). Several gene flow studies have been conducted in the European white oak species $Q$. robur and Q. petraea (Lepais \& Gerber 2011), two closely related species with different adaptations to water availability (Breda et al. 1993, Zanetto et al. 1994). In accordance with results from controlled crosses, paternity analyses at isozymes and gSSRs revealed frequent but asymmetric gene flow between these species (Bacilieri et al. 1996, Streiff et al. 1999, Jensen et al. 2009). Likewise, the very low differentiation at maternally inherited chloroplast (cp) DNA markers between $Q$. robur and $Q$. petraea within geographic regions (Petit et al. 2002) was explained by mainly unidirectional gene flow from $Q$. petraea to $Q$. robur ("pollen swamping") resulting in the invasion of $Q$. petraea into the range of $Q$. robur (Petit et al. 2003). Gene flow analyses in natural multispecies hy- 
brid zones confirmed the unidirectionality of gene flow between both species and revealed partial incompatibilities between other species pairs (Curtu et al. 2009).

Interspecific gene flow can be limited by pre- and post-zygotic isolation mechanisms. However, cross-compatibility between $\mathrm{F}_{1}$ hybrids and pure species (Olrik \& Kjaer 2007, Lepais \& Gerber 2011) suggested that reduced incompatibilities in hybrids might be a route for interspecific gene flow. Accordingly, a gene flow analysis in the four European white oak species Q. robur, Q. petraea, Q. pubsecens and $Q$. pyrenaica suggested that rare $F_{1}$ hybrids are compatible and show a high fidelity to both parental species, thus enabling gene flow between species, but preventing the evolution of hybrids swarms (Lepais \& Gerber 2011). Likewise, incompatibility between a $F_{1} Q$. lobata $\mathrm{x} Q$. douglasii hybrid and both parental species was reduced as compared to interspecific matings suggesting that interspecific gene flow can be facilitated by $\mathrm{F}_{1}$ hybrids (Abraham et al. 2011).

Based on paternity analysis of seeds, a comparatively high level of gene flow was found between Q. petraea and Q. robur (e.g. 7.5\% Q. robur x $Q$. petraea hybrid offspring) (Streiff et al. 1999) which is expected to prevent differentiation between species (Slatkin 1987, Muir \& Schlötterer 2005). Also, based on paternity analyses in mixed stands of the North American red oaks $Q$. rubra, Q. velutina, $Q$. falcata and $Q$. coccinea a considerable percentage of putative hybrids $(>20 \%)$ was described between morphological species (Moran et al. 2012). Since strong viability selection acts on tree seedlings (Müller-Starck 1985), effective gene flow might have been overestimated if selection acts on hybrid seedlings (Muir \& Schlötterer 2005). Thus selection against hybrids is expected to result in a reduction of hybrids from the seed to the adult tree generation.

Based on genetic assignment analyses at gSSRs and isozymes in adult trees of a sym- patric oak stand consisting of the four white oak species $Q$. petraea, $Q$. robur, $Q$. frainetto and $Q$. pubescens, the estimated introgression rate was high at least for some species pairs ranging from $1.7 \%$ between $Q$. robur and $Q$. frainetto, $6.1 \%$ between $Q$. robur and $Q$. petraea to $16.2 \%$ between $Q$. pubescens and Q. frainetto (Curtu et al. 2007a). Remarkably, the overall percentage of hybrids in the seed generation as determined by paternity analysis $(35.9 \%)$ was considerably higher than the proportion of hybrids and introgressive forms (admixture coefficient $<0.9$ ) in the adult tree generation $(20.1 \%)$ which might suggest selection against hybrids (Curtu et al. 2009).

In summary, maintenance of species integrity might be due to high levels of intraspecific crosses and backcrosses as compared for example to interspecific crosses, pre-zygotic isolation for example through hetero-specific pollen discrimination, high hybrid fidelity towards parental species (Lepais \& Gerber 2011), and potentially selection against hybrids in early life stages (Curtu et al. 2009).

Unfortunately, only indirect evidence is available for the "selection against hybrids" hypothesis. Genetic assignment analyses in mixed oak stands in different life stages (seeds, seedlings of different age classes, adult trees) are necessary to provide additional evidence for the reduction of hybrids from the seed to adult tree generation by natural selection. Ideally, hybrids should be monitored by genetic assignment analyses from the seed to the adult tree stage in reciprocal transplant experiments. For this purpose, small tissue samples (e.g. tips of cotelydons) could be collected from seeds before planting, genotyped at species-discriminating markers, and grown to the adult stage. Survival and other fitness-related traits should be scored over the same time period to assess differential survival and fitness of hybrid individuals relative to parental species. Unfortunately, this experiment would last at least 50 years and is difficult to accomplish within one professional life-span. 


\section{Evidence for divergent selection}

Despite frequent recurrent gene flow in oaks, species identity and distinct ecological adaptations are maintained in the area of sympatry (Hipp \& Weber 2008, Curtu et al. 2009). Thus, sympatric oak species often reveal distinct and varied adaptations to water availability (Abrams 1990, Brendel et al. 2008) and have defined ecological niches within sympatric stands suggesting a role of natural selection in maintaining species differences. For example, species in a sympatric oak stand in Central Romania consisting of four interfertile European white oak species were spatially clustered in accordance to their ecological requirements and hybrids occurred predominantly in the contact zones between species in intermediate environments (Curtu et al. 2007a). A lower percentage of putative hybrids in the adult as compared to the seed generation provided additional indirect evidence for selection against hybrids (see above, Curtu et al. 2007a, 2009). Likewise, the distribution of $Q$. robur and Q. petraea in adult sympatric stands is strongly correlated with different ecological requirements with regard to water availability (Cochard et al. 1992, Breda et al. 1993), and in a mixed Q. petraea / Q. pyrenaica stand in Central Spain hybrids were located in "areas of maximum contact" between both parental species in different micro-environments (de Heredia et al. 2009). In the western North American red oak species Q. wislizeni, Q. parvula, Q. agrifolia and $Q$. kelloggii, proportions of hybrids and introgressive forms were more strongly correlated with climate variables than with distance also suggesting ecologically-driven selection (Dodd \& Afzal-Rafii 2004).

In order to quantify selection against species and hybrids, genetic assignment analyses and monitoring of parental species and hybrid performance from seed to adult stage in both parental environments are necessary (see above, reciprocal transplant experiments). Using reciprocal transplants, different local adaptations to leaf herbivory were found in neighboring $Q$. rubra populations (Sork et al. 1993). Given the lower rate of interspecific as compared to intraspecific gene flow, as result of divergent selection even more pronounced differences in fitness-related traits are expected in interspecific transplants between neighboring stands.

As result of interspecific gene flow and incomplete lineage sorting, genetic differentiation at nuclear (Mariette et al. 2002, Muir \& Schlötterer 2005, Craft \& Ashley 2006, Curtu et al. 2011b, Lind \& Gailing 2013, Vidalis et al. 2013) and cpDNA markers (Whittemore \& Schaal 1991, Petit et al. 2002) is very low between closely related hybridizing oak species. For example, analysis of eight genomic microsatellites in seven mixed stands of $Q$. robur and $Q$. petraea revealed that only 1.5 $\%$ of the genetic differentiation was distributed between species (Mariette et al. 2002). Genetic markers with increased interspecific divergence were found between neighboring populations of different taxonomic groups of interfertile oak species among AFLPs (Coart et al. 2002, Mariette et al. 2002), isozymes (Finkeldey 2001), gSSRs (Scotti-Saintagne et al. 2004b, Goicoechea et al. 2012), gene-based EST-SSRs (Sullivan et al. 2013) and Single Nucleotide Polymorphism (SNP) markers (Guichoux et al. 2013). For example, interspecific differentiation between $Q$. petraea and Q. robur at outlier locus ssrQrZAG96 was 22.3\% (Muir \& Schlötterer 2005) and 30.8\% (Curtu et al. 2007b) compared to an average genomic differentiation of less than $3 \%$ at nuclear markers (Mariette et al. 2002). High genetic differentiation at these "outlier loci" was interpreted as result of divergent selection acting on these gene markers or linked makers since divergence was substantially greater than expected under a null hypothesis of neutrality (Scotti-Saintagne et al. 2004b). As result of the reduction of effective interspecific gene flow by divergent selection, linkage disequilibrium (LD) is predicted to be higher in genic regions under divergent selection (outlier regions) than in control (selectively neutral) regions ("divergence hitchhiking") (Via 2009, 2012). Diver- 
gence hitchhiking allows for the accumulation of alleles involved in reproductive isolation between species and thus is a necessary requirement for ecological speciation in sympatry (Via 2012). Accordingly, lower recombination rates were found in outlier regions between $Q$. petraea and Q. robur as compared to a control region (Goicoechea et al. 2012).

The availability of EST resources in oaks enables the development of gene-based markers such as EST-SSRs and SNPs in candidate genes with putative role in adaptive species differences (e.g. drought tolerance related genes) and reproductive isolation between species (e.g. phenology genes) (Durand et al. 2010, Ueno et al. 2010, Ueno et al. 2013). Gene-based EST-SSRs show high transferability between different oak sections (Sullivan et al. 2013) and can be used for comparative outlier screens in different oak species to identify gene families related to adaptive species differences. The eastern North American red oak species $Q$. ellipsoidalis, $Q$. velutina, $Q$. coccinea and $Q$. rubra represent a gradient from the most to least drought tolerant of eastern North American red oaks (Abrams 1990) and occur in different micro-environments with some overlap in the contact zones (Figure 2a). Similarly European white oak species are confined to environments with different water availability (Figure 2b). Outlier analyses using gSSRs and gene-based EST-SSRs revealed outlier loci with putative roles in abiotic stress response, photosynthetic efficiency and the control of flowering time in red oak species (Lind \& Gailing 2013, Sullivan et al. 2013, Lind-Riehl et al. 2014). Accordingly, higher interspecific genetic differentiation was detected between the ecologically different species $Q$. robur and $Q$. petraea at gene-based markers than at anonymous potentially non-coding markers suggesting that functional genomic regions are involved in adaptive species differences (Scotti-Saintagne et al. 2004b). Outlier loci were distributed on nine out of 12 linkage groups revealing a mosaic of regions perme- able to interspecific gene flow interspersed by genomic regions with signatures of divergent selection (Scotti-Saintagne et al. 2004b). Comparative outlier screens in different oak sections could reveal whether some of the same genes are involved in adaptive species differences and reproductive isolation (e.g. drought tolerance, phenology).

Interestingly, Quantitative Trait Loci (QTL) that are associated with species discriminating characters show a similarly wide-spread distribution across linkage groups as outlier genomic regions (Scotti-Saintagne et al. 2004b). Thus, polygenic inheritance was found for most analyzed traits with high interspecific differentiation (Saintagne et al. 2004, Scotti-Saintagne et al. 2004a, Scotti-Saintagne et al. 2004b, Parelle et al. 2007, Gailing 2008, Gailing et al. 2008, Gailing et al. 2013). A major QTL was only detected for water use efficiency in a $Q$. robur full-sib family explaining more that $20 \%$ of the phenotypic variation (Brendel et al. 2008). Since appropriate interspecific crosses were not available, characters discriminating between $Q$. petraea and $Q$. robur were analyzed in intraspecific $Q$. robur crosses. Thus, the number of QTL and the phenotypic variation explained by each QTL could have been underestimated (Gailing et al. 2013). Future studies should analyze whether QTL for adaptive species differences co-locate with outlier genomic regions (Figure 3). For this purpose, genome scans for outlier regions using for example Restriction Site Associated DNA (RAD) markers (Baird et al. 2008) should be performed in different contact zones between species. In the near future, high resolution genetic linkage maps (Bodénès et al. 2012) in $Q$. robur and $Q$. petraea anchored to scaffolds of the sequenced Q. robur genome (Faivre Rampant et al. 2011, Neale \& Kremer 2011) [https://w3.pierroton.inra.fr/Quercus Portal/] will allow to identify the location of outlier genes relative to species discriminating QTL. Reciprocal transplant experiments of seedlings between parental environments could be used 


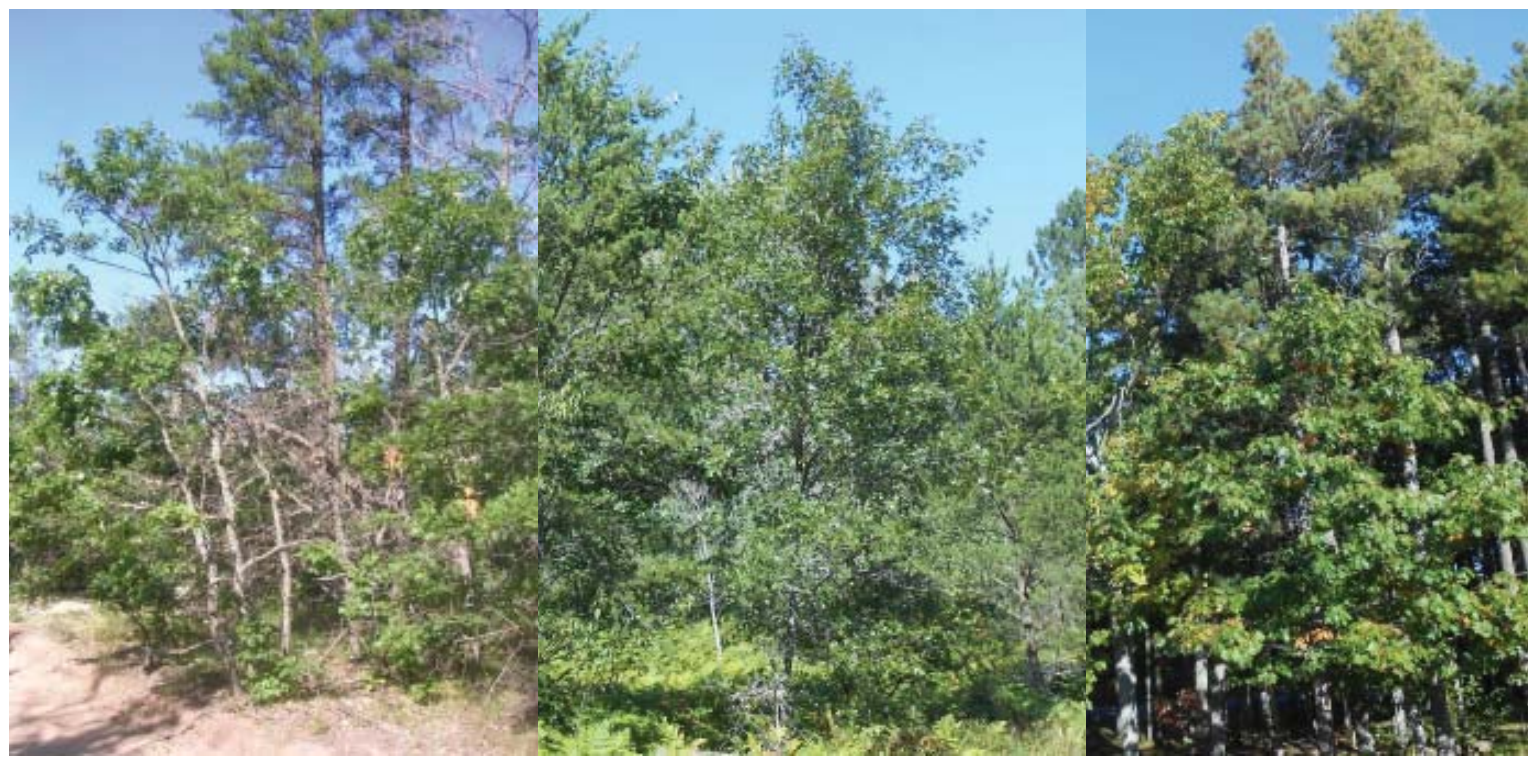

Q. ellipsoidalis

Contact zone

Q. rubra

Photo: O. Gailing

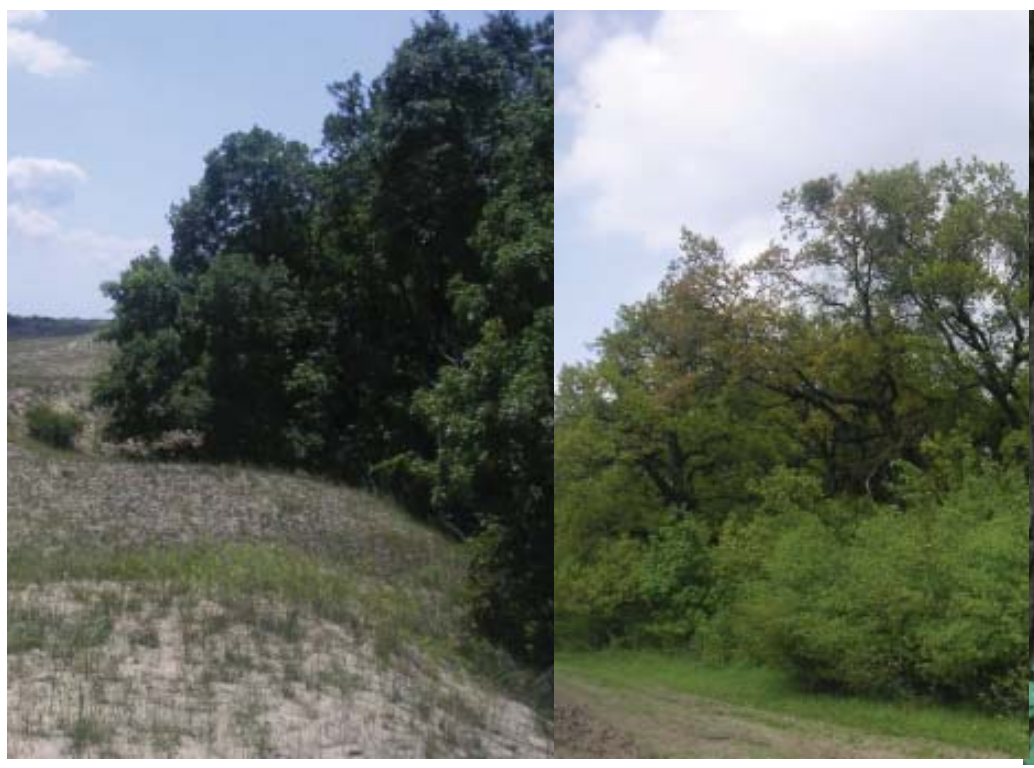

Q. pedunculiflora
Contact zone

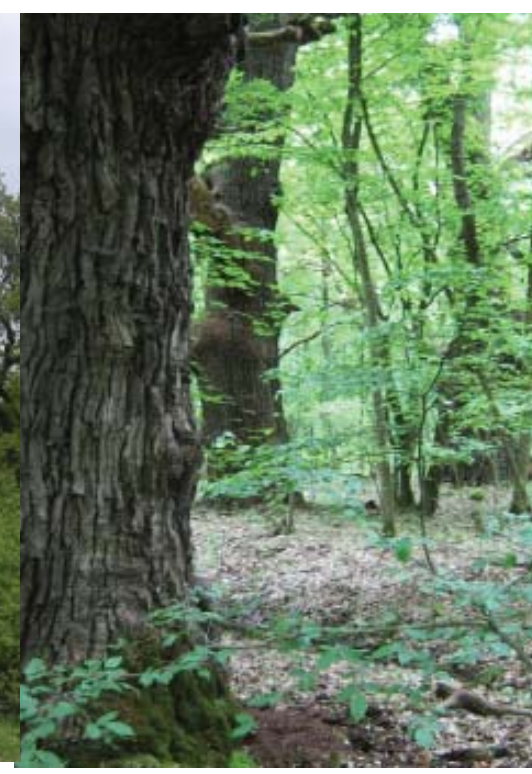

Q. robur

Photo: Al. Curtu

Figure 2 a: Q. ellipsoidalis in dry outwash plains mixed with Jack pine (left), contact zone between Q. ellipsoidalis and Q. rubra (middle), Q. rubra mixed with white pine (right). b: Q. pedunculiflora on sand dunes (left), contact zone between Q. pedunculiflora and Q. robur (Fundeanu-Grivita - Eastern Romania), Q. robur in a mesic site (Central Romania)

to assess the impact of divergent selection on genes located in outlier and/or QTL regions.

\section{Conclusions}

Oaks provide a model to study the genetic basis of species integrity in the face of ongoing in- 

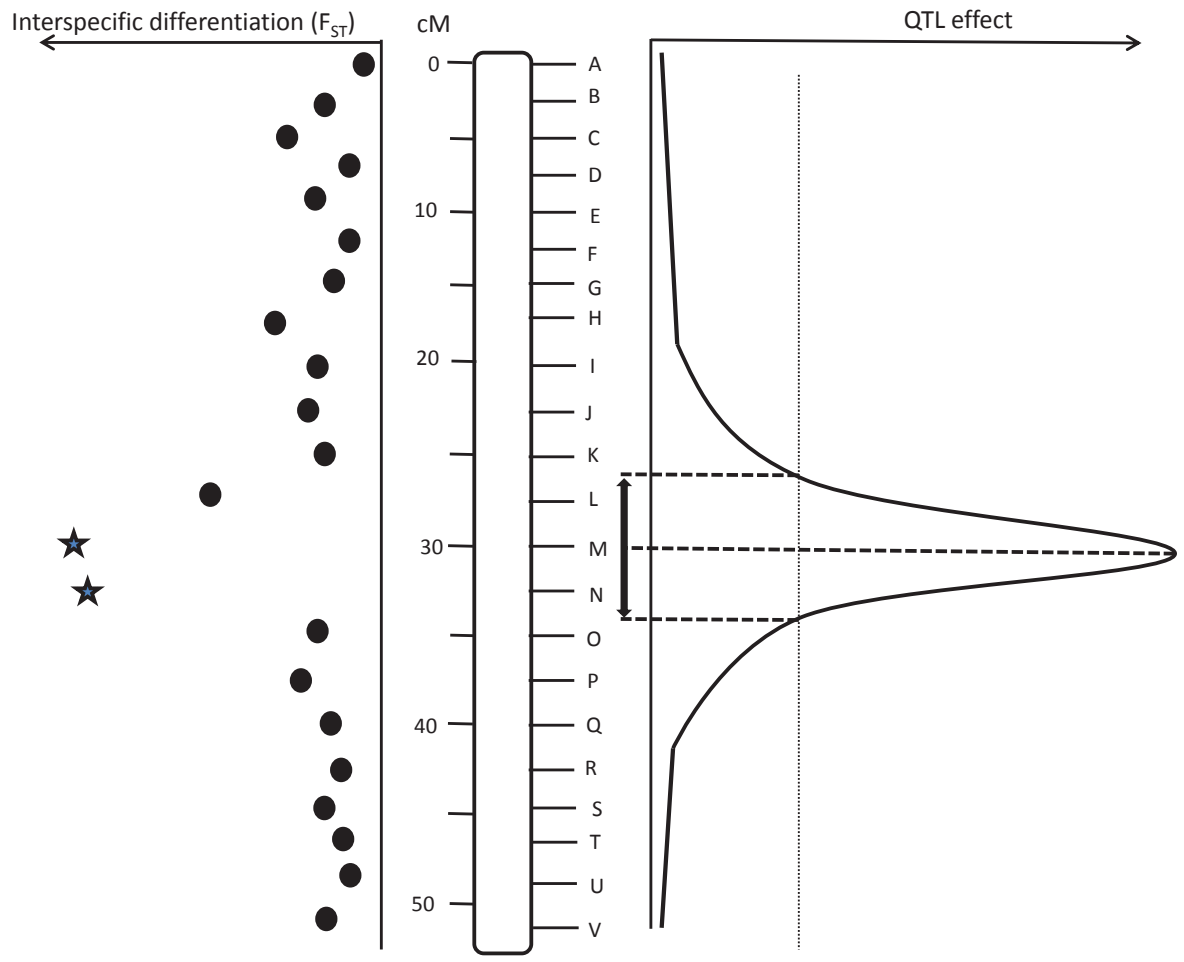

Figure 3 Hypothetical example of co-location of QTL for adaptive species differences with outlier genomic regions. Genome-wide significance for QTL is indicated by a dashed line. Outlier loci under divergent selection and linked loci are designated by stars (loci M, N). According to Via (2009) low interspecific differentiation $\left(F_{S T}\right)$ at locus $\mathrm{L}$ is due to an ancestral polymorphism predating QTL divergence

terspecific gene flow. They also provide an experimental system to identify genomic regions that are involved in species differences. Genome-wide outlier screens can identify genes that are under divergent selection between species. These outlier genes can be plotted on high density genetic linkage maps anchored to a sequenced genome that will become available for $Q$. robur in the near future.

\section{Acknowledgements}

Funding for the analyses on North American red oaks came from the Michigan Technological University (MTU) Research Excellence fund, MTU's Biotech Research Center and Ecosystem Science Center, the USDA McIntire Stennis fund (130951), the Huron Mountain Wildlife Foundation, the Hanes Trust and the 14
NSF Plant Genome Research program (NSF 1025974). Curtu AL was supported by the project UEFISCDI CNCS-RU-TE-73/2010. We thank an anonymous reviewer for constructive comments on the manuscript.

\section{References}

Abbott, R., Albach D., Ansell S., Arntzen J.W., Baird S.J. E., Bierne N., Boughman J., Brelsford A., Buerkle C.A., Buggs R., Butlin R.K., Dieckmann U., Eroukhmanoff F., Grill A., Cahan S.H., Hermansen J.S., Hewitt G., Hudson A.G., Jiggins C., Jones J., Keller B., Marczewski T., Mallet J., Martinez-Rodriguez P., Möst M., Mullen S., Nichols R., Nolte A.W., Parisod C., Pfennig K., Rice A.M., Ritchie M.G., Seifert B., Smadja C.M., Stelkens R., Szymura J.M., Väinölä R., Wolf J.B.W., Zinner D., 2013. Hybridization and speciation. Journal of Evolutionary Biology 26: 229-246. DOI:10.1111/ j.1420-9101.2012.02599.x.

Abraham S.T., Zaya D.N., Koenig W.D., Ashley M.V., 2011. Interspecific and intraspecific pollination pat- 
terns of valley oak, Quercus lobata, in a mixed stand in coastal central California. International Journal of Plant Sciences 172: 691-699. DOI:10.1086/659646.

Abrams M.D., 1990. Adaptations and responses to drought in Quercus species of North-America. Tree Physiology 7: 227-238. DOI:10.1093/treephys/7.1-2-3-4.227.

Aldrich P., Cavender-Bares J., 2011. Quercus. Pages 89129 in C. Kole, editor. Wild crop relatives: Genomic and breeding resources, forest trees. Springer, Berlin. DOI:10.1007/978-3-642-21250-5 6 .

Anderson E.C., Thompson E.A., 2002. A model-based method for identifying species hybrids using multilocus genetic data. Genetics 160: 1217-1229.

Arnold M.L., 2004. Transfer and origin of adaptations through natural hybridization: Were Anderson and Stebbins right? Plant Cell 16: 562-570. DOI:10.1105/ tpc. 160370 .

Arnold M.L., Martin N.H., 2011. Hybrid fitness across time and habitats. Trends in Ecology \& Evolution 25: 530-536. DOI:10.1016/j.tree.2010.06.005.

Ávila F.A., Ángel S.P., López C.R., 2010. Diversity and structure of an oak community in the Cachalú Biological Reserve, Encino (Santander-Colombia). Revista Colombia Forestal 13: 87-116.

Bacilieri R., Ducousso A., Kremer A., 1995. Genetic, morphological, ecological and phenological differentiation between Quercus petraea (Matt.) Liebl. and Quercus robur L. in a mixed stand of Northwest of France. Silvae Genetica 44: 1-10.

Bacilieri R., Ducousso A., Petit R.J., Kremer A., 1996. Mating system and asymmetric hybridization in a mixed stand of European oaks. Evolution 50: 900-908. DOI: $10.2307 / 2410861$.

Baird N. A., Etter P. D., Atwood T.S., Currey M.C., Shiver A.L., Lewis Z.A., Selker E.U., Cresko W.A., Johnson E.A., 2008. Rapid SNP discovery and genetic mapping using sequenced RAD markers. Plos One 3.

Barton N.H., 2001. The role of hybridization in evolution. Molecular Ecology 10: 551-568. DOI:10.1046/j.1365294x.2001.01216.x.

Boavida L.C., Silva J.P., Feijo J.A., 2001. Sexual reproduction in the cork oak (Quercus suber L). - II. Crossing intra- and interspecific barriers. Sexual Plant Reproduction 14: 143-152. DOI:10.1007/s004970100100.

Bodénès C., Chancerel E., Gailing O., Vendramin G.G., Bagnoli F., Durand J., Goicoechea P.G., Soliani C., Villani F., Mattioni C., Koelewijn H.P., Murat F., Salse J., Roussel G., Boury C., Alberto F., Kremer A., Plomion C., 2012. Comparative mapping in the Fagaceae and beyond with EST-SSRs. BMC Plant Biology 12: 153. DOI:10.1186/1471-2229-12-153.

Bodénès C., Joandet S., Laigret F., Kremer A., 1997. Detection of genomic regions differentiating two closely related oak species Quercus petraea (Matt.) Liebl. and Quercus robur L. Heredity 78: 433-444. DOI:10.1038/ hdy.1997.67.

Breda N., Cochard H., Dreyer E., Granier A., 1993. Field comparison of transpiration, stomatal conductance and vulnerability to cavitation of Quercus petraea and $Q$. robur under water-stress. Annales des Sciences Forestières 50: 571-582. DOI:10.1051/forest:19930606.

Brendel O., Le Thiec D., Scotti-Saintagne C., Bodénès C., Kremer A., Guehl J.-M., 2008. Quantitative Trait loci controlling water use efficiency and related traits in Quercus robur L. Tree Genetics and Genomes 4: 263 278. DOI:10.1007/s11295-007-0107-z.

Burns R.M., Honkala B.H., 1990. Silvics of North America, Washington, DC.

Chybicki I.J., Burczyk J., 2013. Seeing the forest through the trees: comprehensive inference on individual mating patterns in a mixed stand of Quercus robur and $Q$. petraea. Annals of Botany 112: 561-574. DOI:10.1093/ aob/mct131.

Coart E., Lamote V., De Loose M., Van Bockstaele E., Lootens P., Roldan-Ruiz I., 2002. AFLP markers demonstrate local genetic differentiation between two indigenous oak species Quercus robur L. and Quercus petraea (Matt.) Liebl in Flemish populations. Theoretical and Applied Genetics 105: 431-439. DOI:10.1007/ s00122-002-0920-6.

Cochard H., Breda N., Granier A., Aussenac G., 1992. Vulnerability to air-embolism of 3 European oak species (Quercus petraea (Matt.) Liebl, Quercus pubescens Willd., Q. robur L.) Annales des Sciences Forestières 49: 225-233. DOI:10.1051/forest:19920302.

Cottam W.P., Tucker J.M., Santamour Jr. F.S., 1982. Oak hybridization at the University of Utah. State Arboretum of Utah, University of Utah.

Craft K.J., Ashley M.V., 2006. Population differentiation among three species of white oak in northeastern Illinois. Canadian Journal of Forest Research 36: 206-215. DOI:10.1139/x05-234.

Craft K.J., Ashley M.V., Koenig W.D., 2002. Limited hybridization between Quercus lobata and Quercus douglasii (Fagaceae) in a mixed stand in central coastal California. American Journal of Botany 89: 1792-1798. DOI:10.3732/ajb.89.11.1792.

Curtu A.-L., 2006. Patterns of genetic variation and hybridization in a mixed oak (Quercus spp.) forest. Cuvillier Verlag, Göttingen.

Curtu A.L., Gailing O., Finkeldey R., 2007a. Evidence for hybridization and introgression within a species-rich oak (Quercus spp.) community. BMC Evolutionary Biology 7: 218. DOI:10.1186/1471-2148-7-218.

Curtu A.L., Gailing O., Finkeldey R., 2009. Patterns of contemporary hybridization inferred from paternity analysis in a four-oak-species forest. BMC Evolutionary Biology 9: 284. DOI:10.1186/1471-2148-9-284.

Curtu A.L., Gailing O., Leinemann L., Finkeldey R., 2007b. Genetic variation and differentiation within a natural community of five oak species (Quercus spp.). Plant Biology 9: 116-126. DOI:10.1055/s-2006924542.

Curtu A.L., Moldovan I.C., Enescu C.M., Craciunesc I., Sofletea N., 2011a. Genetic Differentiation between Quercus frainetto Ten. and Q. pubescens Wild. in Ro- 
mania. Notulae Botanicae Horti Agrobotanici Cluj-Napoca 39: 275-282.

Curtu A.L., Sofletea N., Toader A.V., Enescu M.C., 2011 b. Leaf morphological and genetic differentiation between Quercus robur L. and its closest relative, the drought tolerant Quercus pedunculiflora K. Koch. Annals of Forest Science 68: 1163-1172. DOI:10.1007/s13595011-0105-z.

de Heredia U.L., Valbuena-Carabana M., Cordoba M., Gil L., 2009. Variation components in leaf morphology of recruits of two hybridising oaks $Q$. petraea (Matt.) Liebl. and $Q$. pyrenaica Willd. at small spatial scale. European Journal of Forest Research 128: 543-554. DOI:10.1007/s10342-009-0302-6.

Dodd R.S., Afzal-Rafii Z., 2004. Selection and dispersal in a multispecies oak hybrid zone. Evolution 58: 261-269. DOI:10.1554/03-288.

Durand J., Bodénès C., Chancerel E., Frigero J.-M., Vendramin G.G., Sebastiani F., Buonamici A., Gailing O., Koelewijn H.-P., Villani F., Mattioni C., Cherubini M., Goicoechea P.G., Herran A., Ikaran Z., Cabane C., Ueno S., de Daruvar A., Kremer A., Plomion C., 2010. A fast and cost-effective approach to develop and map EST-SSR markers: oak as a case study. BMC genomics 11: 570. DOI:10.1186/1471-2164-11-570.

Ellstrand N.C., Whitkus R., Rieseberg L. H., 1996. Distribution of spontaneous plant hybrids. Proceedings of the National Academy of Sciences of the United States of America 93: 5090-5093. DOI:10.1073/ pnas.93.10.5090.

Faivre Rampant P., Lesur I., Boussardon C., Bitton F., Martin-Magniette M., Bodenes C., Le Provost G., Berges H., Fluch S., Kremer A., Plomion C., 2011. Analysis of $\mathrm{BAC}$ end sequences in oak, a keystone forest tree species, providing insight into the composition of its genome. BMC genomics 12: 292. DOI:10.1186/14712164-12-292.

Finkeldey R., 2001. Genetic variation of oaks (Quercus spp.) in Switzerland. 1. Allelic diversity and differentiation at isozyme gene loci. Forest Genetics 8: 185-195.

Gailing O., 2008. QTL analysis of leaf morphological characters in a Quercus robur full-sib family (Q. robur $\mathrm{x}$ Q. robur ssp. slavonica). Plant Biology 10: 624-634. DOI:10.1111/j.1438-8677.2008.00063.x.

Gailing O., Bodénès C., Finkeldey R., Kremer A., Plomion C., 2013. Genetic mapping of EST-derived Simple Sequence Repeats (EST-SSRs) to identify QTL for leaf morphological characters in a Quercus robur fullsib family. Tree Genetics \& Genomes 9: 1361-1367. DOI:10.1007/s11295-013-0633-9.

Gailing O., Langenfeld-Heyser R., Polle A., Finkeldey R., 2008. Quantitative trait loci affecting stomatal density and growth in a Quercus robur progeny: implications for the adaptation to changing environments. Global Change Biology 14: 1934-1946. DOI:10.1111/j.13652486.2008.01621.x.

Gailing O., Lind J., Lilleskov E.A., 2012. Leaf morphological and genetic differentiation between Quercus ru- bra L. and Q. elliposidalis E. J. Hill populations in contrasting environments. Plant Systematics and Evolution 298: 1533-1545. DOI:10.1007/s00606-012-0656-y.

Goicoechea P.G., Petit R.J., Kremer A., 2012. Detecting the footprints of divergent selection in oaks with linked markers. Heredity 109: 361-371. DOI:10.1038/ hdy.2012.51.

Guichoux E., Garnier-Gere P., Lagache L., Lang T., Boury C., Petit R. J., 2013. Outlier loci highlight the direction of introgression in oaks. Molecular Ecology 22: 450462. DOI: $10.1111 / \mathrm{mec} .12125$.

Hipp A.L.,Weber J.A., 2008. Taxonomy of Hill's oak (Quercus ellipsoidalis: Fagaceae): Evidence from AFLP data. Systematic Botany 33: 148-158.DOI:10.1600/036 364408783887320 .

Jensen J., Larsen A., Nielsen L. R., Cottrell J., 2009. Hybridization between Quercus robur and Q. petraea in a mixed oak stand in Denmark. Annals of Forest Science 66: 12. DOI:10.1051/forest/2009058.

Jensen R.J., Hokanson S.C., Isebrands J.G., Hancock J.F., 1993. Morphometric variation in oaks of the apostle islands in Wisconsin - evidence of hybridization between Quercus rubra and Q. ellipsoidalis (Fagaceae). American Journal of Botany 80: 1358-1366. DOI: $10.2307 / 2445721$.

Kleinschmit J., Kleinschmit J.R.G., 2000. Quercus robur - Q. petraea: a critical review of the species concept. Glasnik Za sumske Pokuse 37: 441-452.

Kleinschmit J.R.G., Bacilieri R., Kremer A., Roloff A., 1995. Comparison of morphological and genetic traits of pedunculate oak (Quercus robur L.) and sessile oak (Q. petraea (Matt.) Liebl.). Silvae Genetica 44: 256269.

Kremer A., Dupouey J.L., Deans J.D., Cottrell J., Csaikl U., Finkeldey R., Espinel S., Jensen J., Kleinschmit J., Van Dam B., Ducousso A., Forrest I., Lopez de Heredia U., Lowe A.J., Tutkova M., Munro R.C., Steinhoff S., Badeau V., 2002. Leaf morphological differentiation between Quercus robur and Quercus petraea is stable across western European mixed oak stands. Annals of Forest Science 59: 777-787. DOI:10.1051/forest:2002065.

Lagache L., Klein E.K., Guichoux E., Petit R.J., 2013. Fine-scale environmental control of hybridization in oaks. Molecular Ecology 22: 423-436. DOI:10.1111/ mec. 12121.

Lepais O., Gerber S., 2011. Reproductive patterns shape introgression dynamics and species succession within the European white oak complex. Evolution 65: 156170. DOI:10.1111/j.1558-5646.2010.01101.x.

Lepais O., Petit R.J., Guichoux E., Lavabre J.E., Alberto F., Kremer A., Gerber S., 2009. Species relative abundance and direction of introgression in oaks. Molecular Ecology 18: 2228-2242. DOI:10.1111/j.1365294X.2009.04137.x.

Lepais O., Roussel G., Hubert F., Kremer A., Gerber S., 2013. Strength and variability of postmating reproductive isolating barriers between four European white 
oak species. Tree Genetics \& Genomes 9: 841-853. DOI:10.1007/s11295-013-0602-3.

Levin D.A., Francisco-Ortega J., Jansen R.K., 1996. Hybridization and the extinction of rare plant species. Conservation Biology 10: 10-16. DOI:10.1046/j.15231739.1996.10010010.x.

Lind J., Gailing O., 2013. Genetic structure of Quercus rubra L. and Q. ellipsoidalis E.J. Hill populations at gene-based EST-SSR and nuclear SSR markers. Tree Genetics \& Genomes 31: 231-239.

Lind-Riehl J., Sullivan A., Gailing O., 2014. Evidence for selection on a CONSTANS-like gene between two red oak species. Annals of Botany. DOI: 10.1093/aab/mcu 019.

Manos P.S., Doyle J.J., Nixon K.C., 1999. Phylogeny, biogeography, and processes of molecular differentiation in Quercus subgenus Quercus (Fagaceae). Molecular Phylogenetics and Evolution 12: 333-349. DOI:10.1006/ mpev.1999.0614.

Manos P.S., Stanford A.M., 2001. The historical biogeography of Fagaceae: Tracking the tertiary history of temperate and subtropical forests of the Northern Hemisphere. International Journal of Plant Sciences 162 (6 Suppl): 577 - 593. DOI:10.1086/323280.

Mariette S., Cottrell J., Csaikl U.M., Goikoechea P., König A.O., Lowe A.J., Van Dam B.C., Barreneche T., Bodénès C., Streiff R., Burg K., Groppe K., Munro R.C., Tabbener H., Kremer A., 2002. Comparison of levels of genetic diversity detected with AFLP and microsatellite markers within and among mixed Q. petraea (Matt.) Liebl. and Q. robur L. stands. Silvae Genetica 51: 72-79.

Mayr E., 1942. Systematics and the origin of species. Columbia University Press, New York.

McShea W.J., Healy W.M., Devers P., Fearer T., Koch F.H., Stauffer D., Waldon J., 2007. Forestry matters: Decline of oaks will impact wildlife in hardwood forests. Journal of Wildlife Management 71: 1717-1728. DOI:10.2193/2006-169.

Moran E.V., Willis J., Clark J.S., 2012. Genetic evidence for hybridization in red oaks (Quercus Sect. Lobatae, Fagaceae). American Journal of Botany 99: 92-100. DOI:10.3732/ajb.1100023.

Muir G., Schlötterer C., 2005. Evidence for shared ancestral polymorphism rather than recurrent gene flow at microsatellite loci differentiating two hybridising oaks (Quercus spp.). Molecular Ecology 14: 549-561. DOI:10.1111/j.1365-294X.2004.02418.x.

Müller-Starck G., 1985. Genetic differences between "tolerant" and "sensitive" beeches (Fagus sylvatica L.) in an environmentally stressed adult forest stand. Silvae Genetica 34: 241-247.

Neale D.B., Kremer A., 2011. Forest tree genomics: growing resources and applications. Nature Reviews Genetics 12: 111-122. DOI:10.1038/nrg2931.

Neophytou C., Aravanopoulos F.A., Fink S., Dounavi A., 2011. Interfertile oaks in an island environment. II. Limited hybridization between Quercus alnifolia Poech and Q. coccifera L. in a mixed stand. European Journal of Forest Research 130: 623-635. DOI:10.1007/s10342 010-0454-4.

Nixon K.C., 1993. Infrageneric classification of Quercus (Fagaceae) and typification of sectional names. Annales des Sciences Forestières 50, Suppl 1: 25s-34s. DOI:10.1051/forest:19930701.

Olrik D.C., Kjaer E.D., 2007. The reproductive success of a Quercus petraea x $Q$. robur F1-hybrid in backcrossing situations. Annals of Forest Science 64: 37-45. DOI:10.1051/forest:2006086.

Parelle J., Zapater M., Scotti-Saintagne C., Kremer A., Jolivet Y., Dreyer E., Brendel O., 2007. Quantitative trait loci of tolerance to waterlogging in a European oak (Quercus robur L.): physiological relevance and temporal effect patterns. Plant, Cell and Environment 30: 422-434. DOI:10.1111/j.1365-3040.2006.01629.x.

Petit R., Csaikl U., Bordács S., Burg K., Coart E., Cottrell J., van Dam B., Deans D., Dumolin-Lapègue S., Fineschi S., Finkeldey R., Gillies A., Glaz I., Goicoechea P.G., Jensen J.S., König A.O., Lowe A.J., Madsen S.F., Mátyás G., Munro R.C., Olalde M., Pemonge M.-H., Popescu F., Slade D., Tabbener H., Taurchini D., de Vries S.G.M., Ziegenhagen B., Kremer A., 2002. Chloroplast DNA variation in European white oaks. Phylogeography and patterns of diversity based on data from over 2600 populations. Forest Ecology and Management 156: 5-26. DOI:10.1016/S0378-1127(01)00645-4.

Petit R.J., Bodénès C., Ducousso A., Roussel G., Kremer A., 2003. Hybridization as a mechanism of invasion in oaks. New Phytologist 161: 151-164. DOI:10.1046/ j.1469-8137.2003.00944.x.

Pritchard J.K., Stephens M., Donnelly P., 2000. Inference of population structure using multilocus genotype data. Genetics 155: 945-959.

Rieseberg L.H., 1995. The role of hybridization in evolution: old wine in new skins. American Journal of Botany 82: 944-953. DOI: $10.2307 / 2445981$.

Rushton B.S., 1993. Natural hybridization within the genus Quercus. Annales des Sciences Forestières 50: 73s90s. DOI:10.1051/forest:19930707.

Saintagne C., Bodénès C., Barreneche T., Pot D., Plomion C., Kremer A., 2004. Distribution of genomic regions differentiating oak species assessed by QTL detection. Heredity 92: 20-30. DOI:10.1038/sj.hdy.6800358.

Scotti-Saintagne C., Bodénès C., Barreneche T., Bertocchi E., Plomion C., Kremer A., 2004a. Detection of Quantitative Trait Loci controlling bud burst and height growth in Quercus robur L. Theoretical and Applied Genetics 109: 1648-1659. DOI:10.1007/s00122-004-1789-3.

Scotti-Saintagne C., Mariette S., Porth I., Goicoechea P. G., Barreneche T., Bodénès C., Burg K., Kremer A., 2004b. Genome scanning of interspecific differentiation between two closely related oak species (Quercus robur L. and Q. petraea (Matt.) Liebl.). Genetics 168: 16151626. DOI:10.1534/genetics.104.026849.

Sexton J.P., Hangartner S.B., Hoffmann A.A., 2014. Genetic isolation by environment or distance: which pattern of gene flow is most common? Evolution 68: 1-15. 
DOI:10.1111/evo.12258.

Slatkin M., 1987. Gene flow and the geographic structure of natural populations. Science 236: 787-792. DOI:10.1126/science.3576198.

Sork V.L., Stowe K.A., Hochwender C., 1993. Evidence for local adaptation in closely adjacent subpopulations of northern red oak (Quercus rubra L.) expressed as resistance to leaf herbivores. American Naturalist 142: 928-936. DOI:10.1086/285581.

Steinhoff S., 1993. Results of species hybridization with Quercus robur L. and Quercus petraea (Matt) Liebl. Annales des Sciences Forestières 50: 137s-143s. DOI:10.1051/forest:19930713.

Steinhoff S., 1998. Kontrollierte Kreuzungen zwischen Stiel- und Traubeneiche: Ergebnisse und Folgerungen. Allgemeine Forst- und Jagdzeitung 169: 163-168.

Strasburg J.L., Sherman N.A., Wright K.M., Moyle L.C., Willis J.H., Rieseberg L.H., 2012. What can patterns of differentiation across plant genomes tell us about adaptation and speciation? Philosophical Transactions of the Royal Society B-Biological Sciences 367: 364-373. DOI:10.1098/rstb.2011.0199.

Streiff R., Ducousso A., Lexer C., Steinkellner H., Gloessl J., Kremer A., 1999. Pollen dispersal inferred from paternity analysis in a mixed oak stand of Quercus robur L. and Quercus petraea (Matt.) Liebl. Molecular Ecology 8: 831-842. DOI:10.1046/j.1365-294X.1999.00637.x.

Sullivan A., Lind J., McCleary T.S., Romero-Severson J., Gailing O., 2013. Development and characterization of genomic and gene-based microsatellite markers in North American red oak species. Plant Molecular Biology Reporter 31: 231-239. DOI:10.1007/s11105-0120495-6.

Ueno S., Klopp C., Leple J.C., Derory J., Noirot C., Leger V., Prince E., Kremer A., Plomion C., Le Provost G., 2013. Transcriptional profiling of bud dormancy induction and release in oak by next-generation sequencing. BMC genomics 14.

Ueno S., Le Provost G., Leger V., Klopp C., Noirot C., Frigerio J.M., Salin F., Salse J., Abrouk M., Murat F., Brendel O., Derory J., Abadie P., Leger P., Cabane C., Barre A., de Daruvar A., Couloux A., Wincker P., Reviron M.P., Kremer A., Plomion C., 2010. Bioinformatic analysis of ESTs collected by Sanger and pyrosequencing methods for a keystone forest tree species: oak. BMC genomics 11: 24. DOI:10.1186/1471-2164-11650.

Valbuena-Carabana M., Gonzalez-Martinez S.C., Hardy O.J., Gil L., 2007. Fine-scale spatial genetic structure in mixed oak stands with different levels of hybridization. Molecular Ecology 16: 1207-1219. DOI:10.1111/ j.1365-294X.2007.03231.x.

Van Valen L., 1976. Ecological species, multispecies and oaks. Taxon 25: 233-239. DOI:10.2307/1219444.

Via S., 2009. Natural selection in action during speciation. Proceedings of the National Academy of Sciences of the United States of America 106: 9939-9946. DOI:10.1073/pnas.0901397106.

Via S., 2012. Divergence hitchhiking and the spread of genomic isolation during ecological speciation-with-geneflow. Philosophical Transactions of the Royal Society B-Biological Sciences 367: 451-460. DOI:10.1098/ rstb.2011.0260.

Vidalis A., Curtu A.L., Finkeldey R., 2013. Novel SNP development and analysis at a NADP+-specific IDH enzyme gene in a four species mixed oak forest. Plant Biology 15: 126-137. DOI:10.1111/j.14388677.2012.00575.x.

Viscosi V., Antonecchia G., Lepais O., Fortini P., Gerber S., Loy A., 2012. Leaf shape and size differentiation in white oaks: assessment of allometric relationships among three sympatric species and their hybrids. International Journal of Plant Sciences 173: 875-884. DOI:10.1086/667234.

Whittemore A.T., Schaal B.A., 1991. Interspecific gene flow in sympatric oaks. Proceedings of the National Academy of Sciences of the United States of America 88: 2540-2544. DOI:10.1073/pnas.88.6.2540.

Williams J.H., Boecklen W.J., Howard D.J., 2001. Reproductive processes in two oak (Quercus) contact zones with different levels of hybridization. Heredity 87: 680690. DOI:10.1046/j.1365-2540.2001.00968.x.

Wright, S. 1943. Isolation by distance. Genetics 28:114138.

Yucedag C., Gailing O., 2013. Morphological and genetic variation within and among four Quercus petraea and Q. robur natural populations. Turkish Journal of Botany 37: 619-629.

Zanetto A., Roussel G., Kremer A., 1994. Geographic variation of inter-specific differentiation between Quercus robur L. and Quercus petraea (Matt.) Liebl. Forest Genetics 1: 111-123.

Zeng Y.F., Liao W.J., Petit R.J., Zhang D.Y., 2011. Geographic variation in the structure of oak hybrid zones provides insights into the dynamics of speciation. Molecular Ecology 20: 4995-5011. DOI:10.1111/j.1365294X.2011.05354.x. 